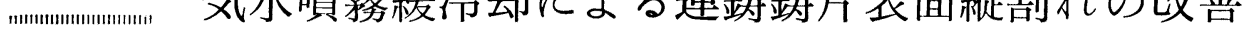

\author{
河野 拓夫*.島孝次*.桑原 達朗* \\ 山本 利樹*. 和気 誠*. 常岡 聡*
}

\section{Improvement of Longitudinal Surface Cracks in CC Slabs by Air-water Mist Cooling Method}

Takuo Kōno, Takatsugu ShImA, Tatsuro KuWABARA

Toshiki Yамамото, Makoto WaKe, and Akira Tsuneoka

\begin{abstract}
Synopsis :
In order to prevent longitudinal surface cracks, a new type of air atomizing nozzle has been developed and applied to continuous casting machines as a secondary cooling system.

1) Air atomizing nozzle is superior to conventional spray nozzle in uniformity of slab surface temperature, in performance reliability and in wider applicability of cooling density.

2) Longitudinal surface cracks are remarkably reduced by this mist cooling method.
\end{abstract}

\section{1. 緒言}

連鋳々片表面の縦割れは，モールド内メニスカス近傍 に和ける凝固の不均一によりその核が発生し，二次冷却 带において，いわゆるII， III領域の脆化域に入るような 冷却や，不均一な冷却により拡大することが報告されて (る1) 3).

したがつて，縦割れを防止するためには，モールド内 での「発生対策」と, 二次冷却帯での「拡大対策」が重 要である.

前者としては, メニスカス近傍での伝熱の不均一が少 なく, しかも, 鋳片に加わる応力, 歪みを小さくするよ らなパウダーや4) モールド冷却条件を検討することが重 要である.

一方，後者としては，まず不均一冷却による局部的な 熱応力の発生を防ぐ必要がある.ささらに, 鋼の脆化温度 域を回避するために, 二次冷却帯の注水比 $(l / \mathrm{kg} \cdot \mathrm{steel})$ を下げ，乙かも均一に冷却することが重要である.

気水噴霧冷却が鋼材の均一冷却手段として優れている といらことは, 古くから知られており, 種々の試みがな されてきだ)。しかし，連鋳の二次冷却への適用は，主 としてノズル自体の問題から一部を除いて车用化に至つ ていないのが現状である.

そこで本報告では，この気水噴霧冷却の利点を生かす ために新たに開発したノズルの構造と特性, 及び気水噴

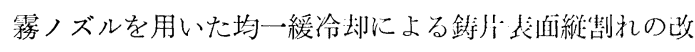
善効果について述べる.

\section{2. 気水噴霧冷却用ノズルの構造と特性}

従来の気水噴霧ノズルは,

（1）構造が複雑で吐出口断面積が小さく，ズル詰 まりが発生しやすい.

（2）1個のノズルがカバーできる水量範图が狭い.

（3）連鋳のロール間で散水する場全，均一散水幅が 狭いために，鋳片幅力问に多数のノズルを䦿湜する必要 があり，整備性が悪い.

などの理由で，連鋳では寒用化が困難であつた。

そこで，まずこれらの問題を解決する連銤二次冷却用 気水噴霧ノズルの開発が必要となつた。

以下にノズルの構造と特性について述べる.

\section{$2 \cdot 1$ 気水噴霧ノズルの構造}

Fig. 1 に気水噴霧ノズルの榗造を示与. ノズルは円 筒部とその先端に設けられた内径 $10 \sim 20 \mathrm{~mm}$ の充压 室, 及びスリット状の吐出口から成立つている。あらか じめ混合された冷却水と加圧空気は, 円简内へ送り込ま れ, 充圧室を経て吐出口より噴蓩状態となつて吐出す る. 吐出角度及び最大吐出流量は, スリットの愿さ $d$, 及び幅 $l$ を変更することにより制御可能である.

\section{$2 \cdot 2$ 気水噴霧冷却ノズルの特性}

\section{$2 \cdot 2 \cdot 1$ 実験方法}



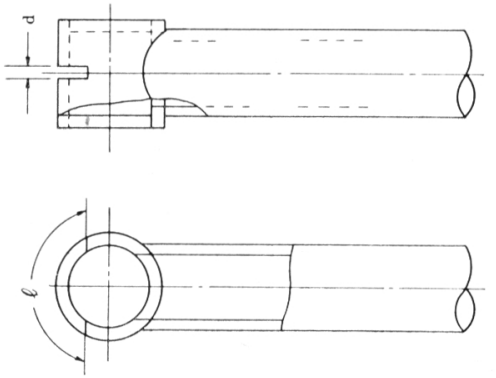

Fig. 1. Tip of air atomizing nozzle.

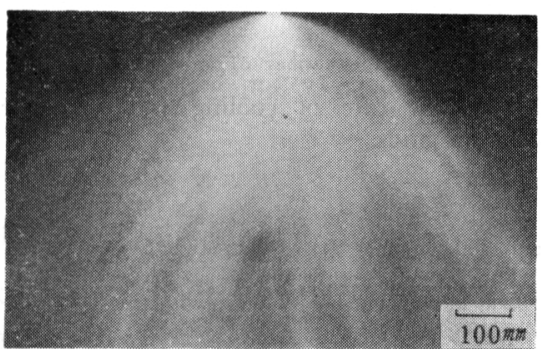

Photo. 1. Spray by an air atomizing nozzle.

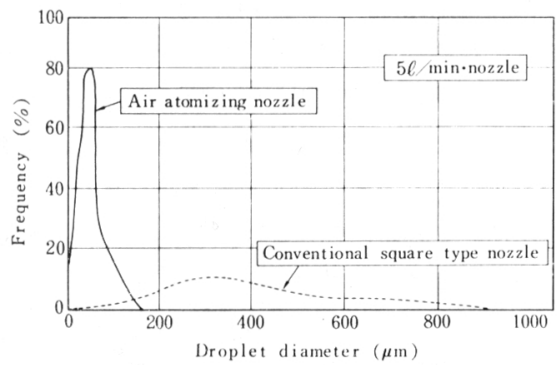

Fig. 2. Distribution of droplet diameter.

気水噴霧ノズルの特性を評価するために，液滴径分 布, 同一デザインのノズルで適正に使用できる水量範 囲, 及び幅方向の散水密度分布を測定した．まず，液滴 径分布は，透明なガラス板に白色粉末を凝着させ，それ を瞬間的に噴霧滴中に置いた時の液滴の痕跡を顕微鏡写 真で測定した.

また, 幅方向の散水密度分布は, 気水噴霧ノズルの先 端より $300 \mathrm{~mm}$ の位置で, 幅 $100 \mathrm{~mm}$ 毎に区切つた容 器で捕集した水量より求めた.

\section{$2 \cdot 2 \cdot 2$ 実験結果及び考察}

Photo. 1 に示寸ように気水噴霧, ズルは, 均一かつ 微細な霧状の噴霧状態を呈している。

Fig. 2 に気水噴霧ノズルとスクェア型スプレーノズ ルの液滴径分布測定結果を示す. 冷却水水量は, いずれ のノズルも， $5 \mathrm{l} / \mathrm{min}$ である. 気水噴霧ノズルの場合, 液滴径はスプレー冷却の場合より小さく, しかも均一な

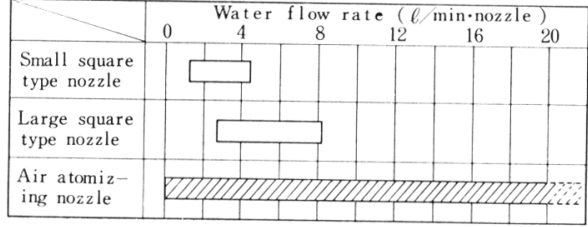

Fig. 3. Applicable range of various nozzle.

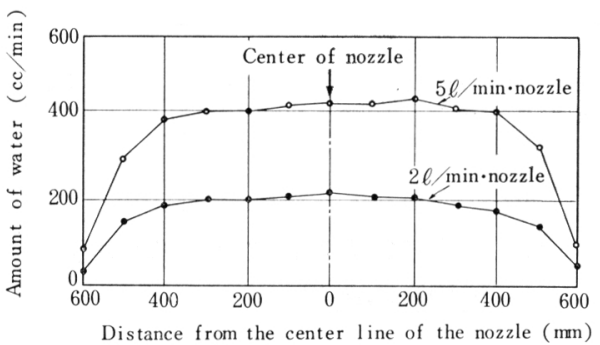

Fig. 4. Uniformity of spray pattern by the air atomizing nozzle.

液滴になつていることがわかる。

Fig. 3 は，同一デザインのノズルで適正に使用でき る水量範囲を示したものである，当所で使用している強 冷却用スプレーノズルが $3 \sim 8 l / \mathrm{min}$ の範囲でしか使用 できないのに対し，気水噴霧ノズルの場合には $0 \sim 20 l$ $/ \mathrm{min}$ 以上の広い範用で使用できる。これは, 気水噴霧 ノズルの吐出口断面積が約 $70 \mathrm{~mm}^{2}$ とスプレーノズルに 比べて大きく，水量増加が容易なことと，水压を利用せ ず，加圧空気を用いて冷却水を加速するため，低水量域 でも安定した噴霧状態が得られることによる.

Fig. 4 は, 気水噴霧ノズルの幅方向の散水密度分布を 示したものである. 図は, Photo. 1 と同一方向の散水 状況を示している，図からわかるよらに，このノズル は, 水量の多少によらず，幅方向に広く，乙か子均一な 散水密度分布が得られる。

このよらに気水噴霧ノズルは，連鋳の二次冷却用ノズ ルが具備すべき条件を汪とんど満たしている。すなわ ち,

（1）同一のノズルで, 緩冷却, 強冷却を問わず, 幅 広い冷却に対応できる。

（2）微細かつ均一な液滴が得られ，冷却の均一性に 優れている.

（3）ノズル吐出口径が大きく，ノズル詰まりの危険 性が少ない，そのため，二次冷却帯の信頼性が向上す 万。

（4）幅方向に広く，乙か子均一な散水密度分布が得 られるため, 従来のスクェア型ノズルに比べて, ノズル 


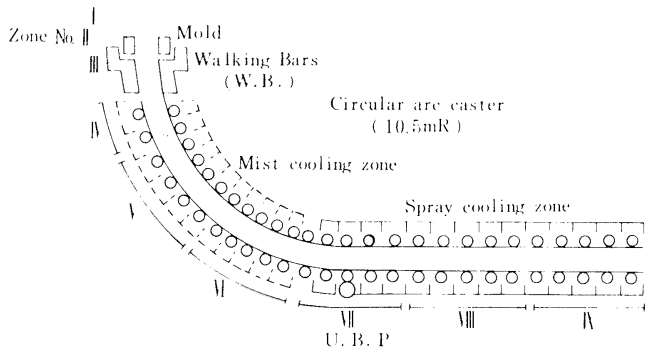

Fig. 5. Secondary cooling profile used for experiments.

個数を大幅に減少できる.

\section{3. 気水噴霧緩冷却による鋳片表面 縦割れの改善}

前述した特性を持つ気水噴霧ノズルを実際に連鋳の二 次冷却带に設置して鋳造実験を行つた.

\section{$3 \cdot 1$ 実験方法}

\section{$3 \cdot 1 \cdot 1$ 二次冷却設備概要}

$10.5 \mathrm{mR}$ の $\mathrm{S}$ 型連鋳機の二次冷却設備を Fig. 5 に 示すように改造した. すなわち，モールド直下の，クイ ックチェンジスタンド内にウォーキングバー（以下，W. B. と記す)を設置した．W．．は鋳片を上下両面より面 支持するため，溶鋼静压によるバルジングを生じさせる ことなく，高温の凝固シェルを引き抜くことができる. また，この間，均一な間接冷却を行うことによつて鋳片 表面の熱応力を小さく抑えることができるなどの利点が ある6). また，W. B. 直下から矯正点近傍までは気水噴 霧冷却帯に改造して, 均一緩冷却による縦割れの拡大防 止を水らつた。一方, 気水噴霧冷却帯以降は, 従来のス プレー冷却設備のままとした. しかし, 緩冷却鋳造テス トに当たつては鋼のIII領域脆化域を高温側に回避してコ 一ナー横割れを防止する目的から，スプレー散水は行わ なかつた。

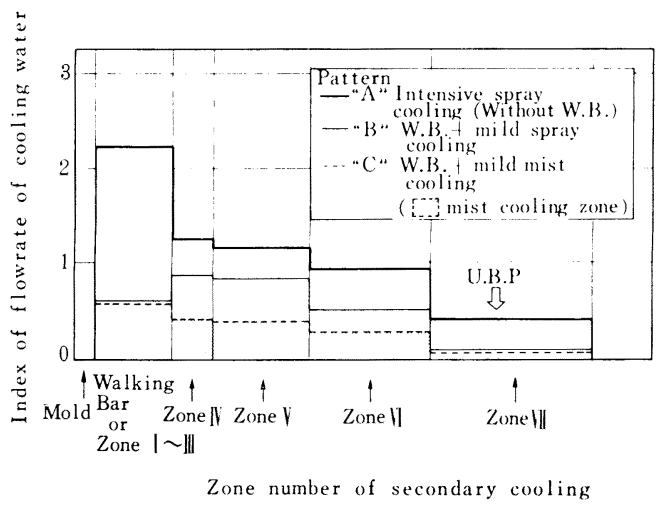

Fig. 6. Flow rate of cooling water in various cooling methods.

\section{$3 \cdot 1 \cdot 2$ 鋳造条件}

Table 1 に実験に用いた鋼の代䘚組成を示す。いず れも，包晶領域の[C]組成を有する中炭素鋼である。ま た鋳造条件として，鋳片寸法は偏平比の大きい $250 \mathrm{~mm}$ 厚 $\times 1900 \mathrm{~mm}$ 幅, 鋳造速度は $1.2 \mathrm{~m} / \mathrm{min} \sim 1.5 \mathrm{~m} / \mathrm{min}$ を選んだ. 注水比は，0.4〜 $1.3 \mathrm{l} / \mathrm{kg}$ steel とした. Fig. 6 にとれぞれの二次冷却パターンのゾーン別散水密度を 示す。パターンAは W. B., 父水噴霧冷却を使用しない ロール方式スプレー強冷却パターンで, 從米の二次冷却 パターンである。それに対し，パターンB拈よび $\mathrm{C} は ，$ W. B. を使用した緩泠却パターンであつて, ハターン B はスプレー方式によるものであり，パターン $\mathrm{C} は, \mathrm{~N} \sim$ Vゾーンに気水噴霧冷却法を採用したものである。 ま

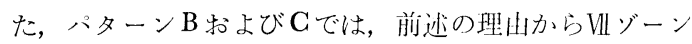
以降は, 鋳片の散水は行つていない.

ここでパターン $\mathrm{C}$ の注水比をパターン Bの $1 / 2$ にした のは次の理由による.

後述するよらに気水噴霧冷却はスプレー冷却の汪ぼ 2 倍の冷却能がある。したがつて鋳师表自温度を同じにす るためには，パターンCはパターンBの $1 / 2$ の水量にな

Table 1. Chemical composition of tested materials and casting conditions.

\begin{tabular}{|c|c|c|c|c|c|c|c|c|c|}
\hline \multirow[b]{2}{*}{ Steel grade } & \multicolumn{6}{|c|}{ Chemical composition(\%) } & \multicolumn{3}{|c|}{ Casting condition } \\
\hline & $\mathrm{C}$ & $\mathrm{Si}$ & $\mathrm{Mn}$ & $\mathrm{P}$ & $\mathrm{S}$ & $\begin{array}{c}\text { Total } \\
\Lambda l\end{array}$ & $\begin{array}{l}\text { Slab size } \\
(m m)\end{array}$ & $\begin{array}{l}\text { Casting speed } \\
(\mathrm{m} / \mathrm{min})\end{array}$ & $\begin{array}{l}\text { Specific cooling } \\
\text { ratio( } l / \text { kg steel })\end{array}$ \\
\hline $\begin{array}{l}\text { Al Killed } \\
\text { Steel for } \\
\text { hot coil }\end{array}$ & $\begin{array}{l}0.10 \\
1 \\
0.15\end{array}$ & trace & $\begin{array}{l}0.30 \\
1 \\
0.50\end{array}$ & $\begin{array}{l}0.013 \\
1 \\
0.018\end{array}$ & $\begin{array}{l}0.015 \\
\stackrel{1}{0} \\
0.020\end{array}$ & $\begin{array}{l}0.010 \\
\stackrel{1}{ } \\
0.030\end{array}$ & $\begin{array}{c}\text { Thickness } \\
250\end{array}$ & 1. 2 & 0.40 \\
\hline $\begin{array}{l}\text { Al-Si Killed } \\
\text { Steel for } \\
\text { hot coil }\end{array}$ & $\begin{array}{l}0.11 \\
\text { ? } 16\end{array}$ & $\begin{array}{l}0.10 \\
? \\
0.30\end{array}$ & $\begin{array}{l}0.40 \\
\stackrel{2}{0} \\
0.60\end{array}$ & $\begin{array}{l}0.013 \\
\stackrel{1}{0.018}\end{array}$ & $\begin{array}{l}0.015 \\
\stackrel{1}{0.020}\end{array}$ & $\begin{array}{l}0.004 \\
\stackrel{?}{0} \\
0.040\end{array}$ & $\begin{array}{l}\text { Width } \\
1900\end{array}$ & 1.5 & 1. 30 \\
\hline $\begin{array}{l}\text { Al Si Killed } \\
\text { Steel for } \\
\text { plate }\end{array}$ & $\begin{array}{l}0.11 \\
1 \\
0.16\end{array}$ & $\begin{array}{l}0.15 \\
? \\
0.30\end{array}$ & $\begin{array}{l}0.60 \\
\quad \begin{array}{l}1 \\
0.90\end{array}\end{array}$ & $\begin{array}{l}0.013 \\
l \\
0.018\end{array}$ & $\begin{array}{l}0.015 \\
l \\
0.020\end{array}$ & $\begin{array}{l}0.005 \\
? \\
0 . \stackrel{045}{0}\end{array}$ & & & \\
\hline
\end{tabular}


a) W.B.t-Spray cooling $(0.80 \% / \mathrm{kg}$ steel $)$

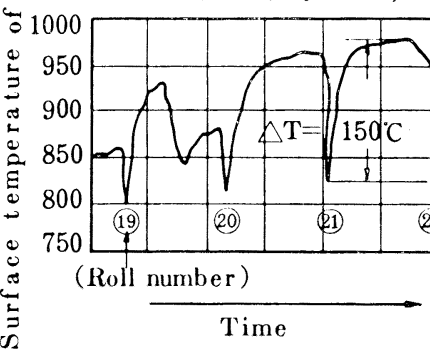

b) W.B. + Mist cooling $(0.40 \ell / k g$ st eel $)$

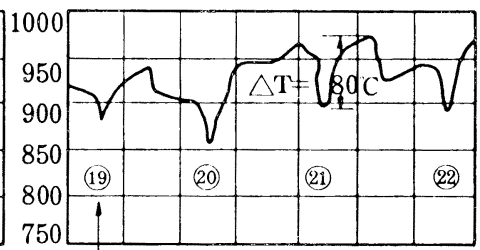

(Roll number)

Time

Fig. 7. The change of surface temperature of slab during casting.

る.

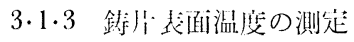

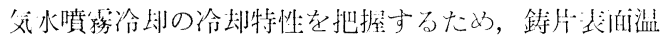
度を測定した，测定には，溶符式の熱電対を用い, メニ スカスト約 $5 \mathrm{~m}, 15 \mathrm{~m}$ の位掼で鋳片幅中央部とエッジ から $25 \mathrm{~mm}$ の锠の温度を測定した。

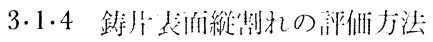

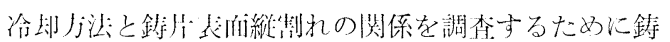

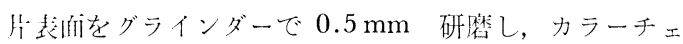

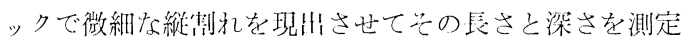

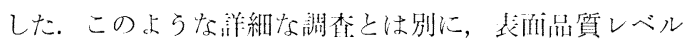

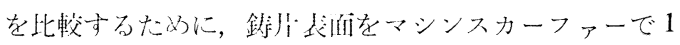

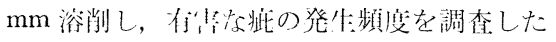

\section{$3 \cdot 2$ 実験結果および考察}

\section{$3 \cdot 2 \cdot 1$ 鋳师冷却特性}

Fig. 7 に, 溶差式熱电刘で测走した鋳片主面幅中央部 の温度プロフィルを示す。测定位置はィニスカス下約 5 mである。

図から明らかなよらに, 父水噴袼冷却はスプレー冷却 の約 $1 / 2$ の水星で，ほぼ同じ䤣牌面温度が得られてお 门スプレー冷却に比べて父水噴霧冷却の冷却能は，ほぼ 2 倍施ることがわかる。また，鋳片表面の温度振幅は， スゾレー冷却侍の $150^{\circ} \mathrm{C}$ に刘し, 気水噴霧冷却時は 80 ${ }^{\circ} \mathrm{C}$ と半減して少り，温度振幅の少ない泠却法であると 光る。

このよらな抜熱登動の相違は，Fig. 8 のような抜熱 モデルを考えることにより説明できる. スプレー冷却の

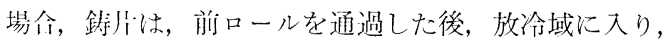
復熱する，次に， メソ゚レー域を通過する際に笖激かつ局 部的に冷却される反面，比力を失つた過剩の水が流れお らる濡れ暨域あるいは汶清域では，水蒸父膜に遮断され

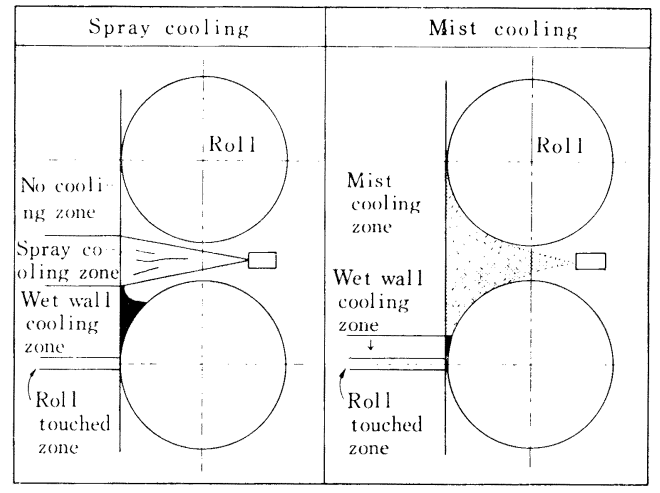

Fig. 8. Schematic display showing the differences of cooling behaviour between spray cooling and mist cooling.

て，抜熱効摔は悪くなる。一方，気水噴霧冷却では口， ール間のほとんどの領域が, ミスト域になつて括り, 冷 却面箖が広いらえ, 鋳片冷却時に発生する水蒸気膜を加 圧空気で，常に排除するため，拔熱効率が良くなる。ま た温度振幅についても, 浸漬域が狭く, 過剩の水がロー ルー鋳片間に溜まることの少ない気水噴霧冷却の方が 小 さくなるものと考えられる.

Fig. 7a) では, スプレー域での温度降下が現れていな い部分があるが，これは，測定点が，ノズル直下に位置 していなからたためと思われる。

Fig. 9 に鋳片幅方向の温度プロフィルを示す。図は, 鋳片幅方向中央部とエッジから $25 \mathrm{~mm}$ の点の測温結果 からの推定図であるが，気水噴霧冷却では，スプレー冷 却のように過剩な水が鋳片エッジ部より流れ落ちること がなくなるために鋳片エッジ部の温度低下が小さくなる ものと推定される.

$3 \cdot 2 \cdot 2$ 鋳片表面縦割れ調查結果

Fig. 10 にグラインダー研磨とカラーチェックで現出 

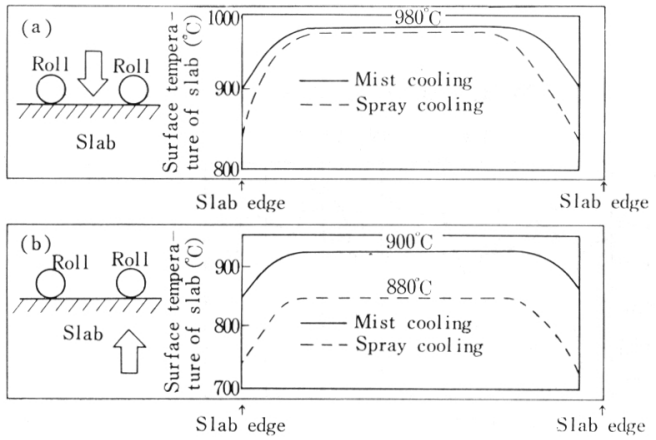

(a) Measured at the center of roll pitch

(b) Measured at the bottom of roll

Fig. 9. Profile of surface temperature of cross section.

させた縦割れの長さと深さの関係を示す。二次冷却パタ ーンは, Fig. 6 に示したパターンA, パターンB执よ びパターンCの 3 種類を用いた.

図よりパターンGは, 同一長さの縦割れでもパターン A，Bに比較して深さが著しく減少している.たと光 ば, $30 \mathrm{~mm}$ 長さの縦割れについてみると, パターン $\mathrm{C}$ では割れ深さはたかだか $1 \mathrm{~mm}$ であるのに対して，パタ ーンA, Bでは $3 \mathrm{~mm}$ 以上にも達するものがある. Photo. 2 にパターンA拈よび $\mathrm{C}$ で発生した典型的な縦 割れの断面を示す，パターンCでは, 縦割れは, デンド ライト樹間の浅い位置で止まつているが，パターンAで は, 縦割孔は, 深く進行し, オーステナイト粒界割れの

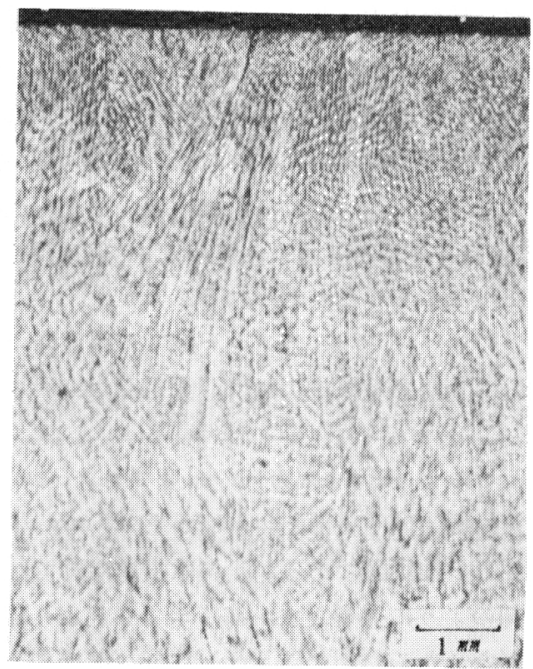

a) Mild mist cooling

$$
\text { ("C"pattern) }
$$

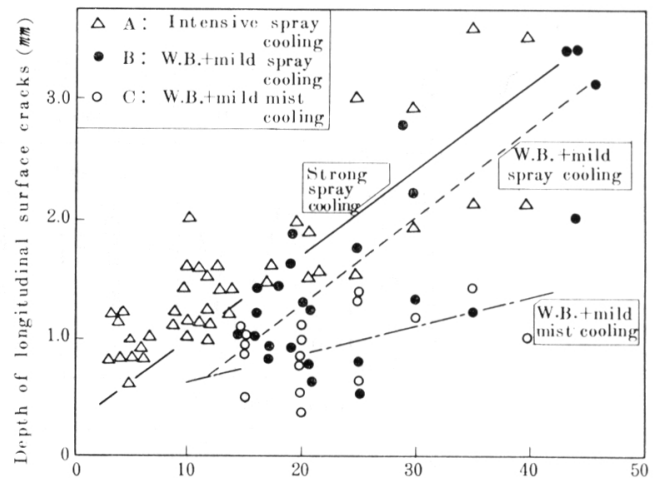

Length of longitudinal surface eracks $(m m)$

Fig. 10. Relation between length and depth of longitudinal surface cracks in various cooling methods.

様相を呈している.

Table 2 は, 縦割れ発生個数を示す指数で冷却パター

Table 2. Index of the number of longitudinal cracks.

\begin{tabular}{ccc}
\hline & $\begin{array}{l}\text { Small cracks and } \\
\text { large cracks }\end{array}$ & Large cracks only \\
\hline "A "pattern & 18.48 & 0.30 \\
"B "pattern & 5.97 & 0.09 \\
"C "pattern & 1.00 & 0.03 \\
\hline
\end{tabular}

small crack $\leq 20 \mathrm{~mm}$ long large crack $>20 \mathrm{~mm}$ long

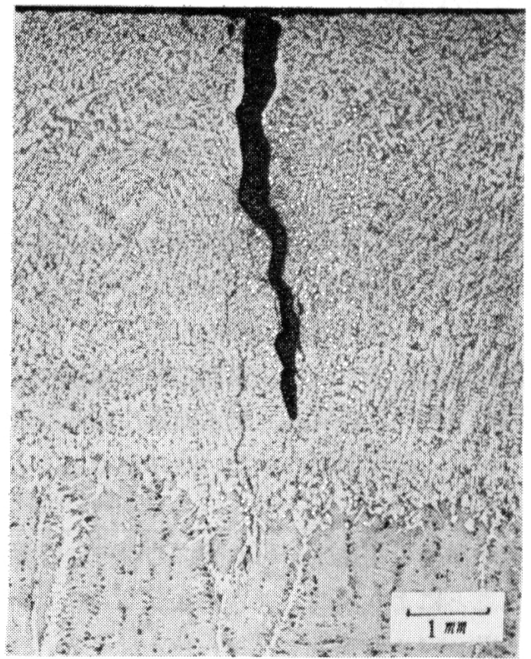

b) Intensive spray cooling ( " $A$ " pattern)

Photo. 2. Typical examples of crack morphology showing the effect of mild mist cooling. 
ンごとに比較したものである。やはりパターンCが最も 割㣗発生指数が低く，無手人れ圧延結果も艮好であつ た.

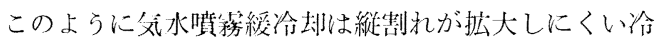
却方法である。

以上の結果について鋼の高温物性の面から考察する。

鋼は高温域に I， II およびIIIの脆化温度域を有するこ とが知られている7) 9)．Ｉ領域の脆化原因は固相線温度 近傍でのデンドライトアーム間の液膜脆化で苏る778).

また，II 領域は，金相学的調查によるとオーステナイト 粒界での MnS などの析出物による脆化であることが知 られている. したがつてフィルム状サルファイドが時間 経過とともに球状化して延性を回復すれば脆化現象は消 失することが確か奶られている8). さらに領域は $\gamma \rightarrow$ $\alpha$ 変態に関する脆化であることがこれまでの調查でわか つている ${ }^{8) 9}$.

これらの知見をもとに Fig. 11 に示すよらな温度と 経過時間の両軸で衣した I， II およびIIIの脆化マップを 作成した．脆化マップの作成に当たつては次のことを前 提とした。

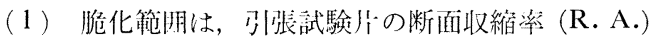
の优が $60 \%$ 以下の笙间とした。これは，R.A. 値 60 \%以下といら条件で尖操業における鋳片の割れ感受性 が良く説明できるといら知見に基ついた ${ }^{10)}$.

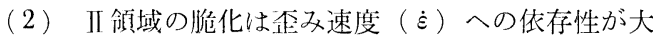
きいが連鋳㙨のロールピッチ，及び鋳造速度から推定寸 る上 $\dot{\varepsilon}=5 \times 10^{-2} \mathrm{~s}^{-1}$ 程度の䀇が適当である.なおこの 值は，連続鋳造におけるバルジング歪みに起因する歪み

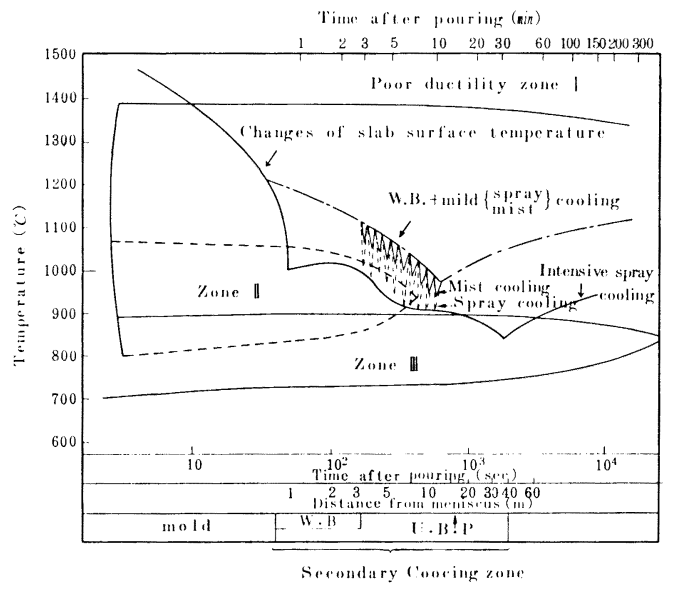

Fig. 11. Schematic diagram of poor ductility zone of steel and slab temperature change, showing the effect of mist cooling.

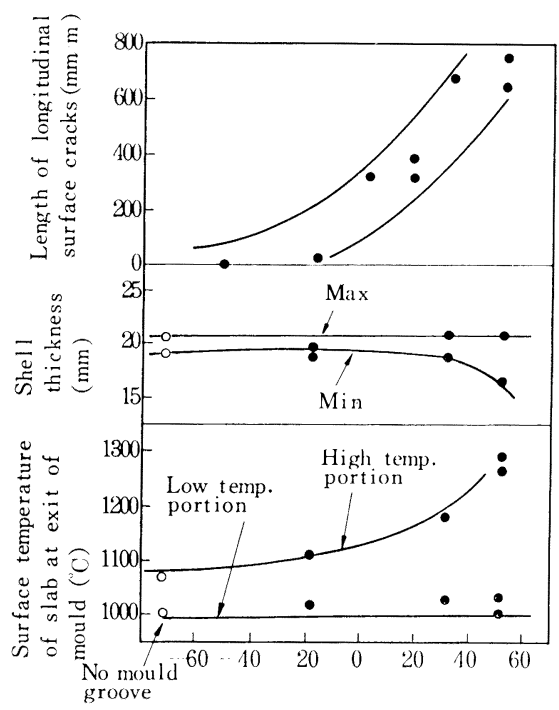

Distance from the groove top to the liquid level ( $\mathrm{mm}$ )

Fig. 12. Surface temperature, shell thickness and longitudinal cracks showing the large temperature difference at the mold exit ${ }^{11}{ }^{11)}$.

速度は 10-2 $\mathrm{S}^{-1}$ とする知見9) とほぼ一致する.

今, この脆化挙動に連鋳機内での鋳片表面温度推移を 重む合わせてみる，図中各種の曲線は，異なる二次冷却 条件で 鋳造した 時の 鋳片表面幅中央部の 温度推移を示 す.ただし，その温度は，Fig. 7 で示した実測值より も， $100^{\circ} \mathrm{C}$ 高く描かれている。これは，著者らが行つた 人工疵付モールドテスト結果1112)から, 凝固遅れを生じ た部分の鋳片表面温度を推定して図示したためである。

つまり Fig. 12 に示すように，モールドに付计た人工疵 により凝固遅れを生じるとともに繸割れの核が発生した 部分の鋳片表面温度は, 正常部に比べ, $200^{\circ} \mathrm{C} \sim 300^{\circ} \mathrm{C}$ 高い，もちろん、これはモールド内に，深さ $0.1 \sim 0.3$ $\mathrm{mm}$, 幅 $1.0 \sim 3.0 \mathrm{~mm}$, 長さ $150 \mathrm{~mm}$ の人工疵を付けた 例であり, 実操業で経験する縱割れの場合, 凝固遅れ部 と正常部の温度差は，これほど大きくない。また，この 温度差は, 二次冷却帯に入り，小さくなることが予想さ れる，そこで，ここでは，正常部より $100^{\circ} \mathrm{C}$ 表面温度 が高くなるような凝固遅部を想定し，そこに発生した 縦割れの核の拡大を考えることにした。

Fig. 11 によればモールドに鋳込まれた溶鋼は，凝固 する際, メニスカス近傍で I 領域を通過する.この際, $\delta \rightarrow \gamma$ 変態に伴う不均一凝固により, 縱割れの核が発生 する，これは，包晶変態- $\mathrm{Ar}_{4}$ 変態を伴ら鋼の場合には 特に著しい。パターンAでは，モールド直下からクイッ 
クチェンジスタンド内全域でスプレーによる強冷却を受 けてII 領域脆化域に入り，矯正点近傍では，更にIII領域 に入つている. したがって, 縦割れの拡大は著しく促進 され，割れの先端は $\gamma$ 粘界割れの様相を呈する ${ }^{2}$ 。 これ はPhoto. 2b) に示した縦割饥断面組織とも良く一致寸 る.

一方，パターンBに执いては，モールド直下ではII 領 域を脱して抢り有利である。 しかし，その後のスプレー 冷却による温度振幅のため, 局所的にII 領域に入つてし まい，縱割れの改善は望めるが不完全である。

パターン $\mathrm{C}$ はパターン $\mathrm{B}$ と同様にモールド直下では,

II 領域を回避して叔り，乙かも温度振幅が小さいために 縦割れの㧨大防止には非常に有利な冷却パターンであ る. Photo. 2a) は，このような冷却条件で鋳造された 鋳片の縦割れ断面組織であるが，割れはデンドライトア 一ム間で止宗つており，II領域で拡大されていないこと を示している.

以上の考察は，幾つかの仮定を含んで拈り，定量的な 議論をするには, 今後の研究を待たねばならない。しか し，このよらな考方基づいて行つている実際の連鋳 操業に挍いて, 鋳片表面疪, なかでも繸割れ疵を大幅に 改善することができており，この考え方に大きな䛊りは ないと思わ机る。

\section{$3 \cdot 2 \cdot 3$ 実機操業結果}

以上の上万に，気水噴霧緩冷却法が，鋳片埊面の縦割 れ防止之設備の信頼性の両面に優孔ているとの実験結果 から, 大分製鉄所では，4号，5号連鋳機の二次冷却設 備を全面的に気水噴霧冷却法汇改造し，それぞれ，昭和 55 年 8 月, 昭和 56 年 4 月に操業を開始した.

設備としては，Fig. 5 に示したものと同様，モール ド直下に W. B. を設置し，それ以降，矯正点近傍まで を, 気水噴霧冷却带之した。

Fig. 13 に，実機で鋳造した $40 \mathrm{kgf} / \mathrm{mm}^{2}$ 級厚板材の 表面品質を示す，図には，比較のために，従来の口ール 方式スプレー強冷却時の表面品質もあわせて示したが, 気水噴霧緩冷却では有害な縦割れは, 全く発生して拈ら ず，現在，Table 1 亿示した鋼種は，すべて，ノースカ 一フ無手入れで, 圧延工程へ直送している.
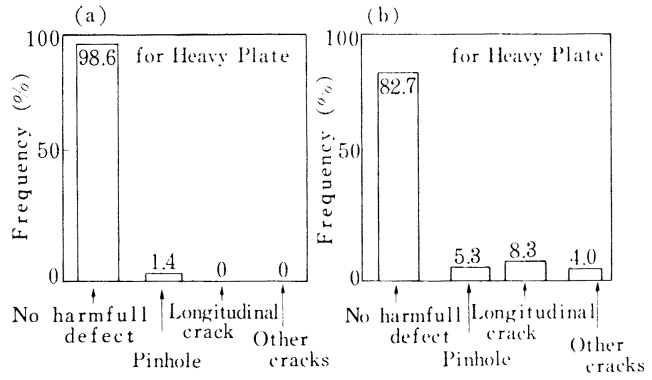

(a) Mild mist cooling

(b) Conventional spray cooling

Fig. 13. Slab surface quality by the improved secondary cooling method.

\section{4. 結 言}

連鋳鋳片の表面縦割れを防止するために気水噴蓩ノズ ルを開発し，実機に適用して以下の結論を得た。

（1）気水噴霧ノズルは，冷却が均一でノズル詰まり が発生せず，しかも，広い流量範囲で使用可能で西る。

（2）気水噴霧緩冷却法に上り，鋳片衣面縦割れを大 幅に改善することができた.

試験の遂行にあたり，多大の衘援助をいただいた新日 本製鉄(株)の益守照道，三隅秀幸，淌浜秀行ならびに麻 生寿郎の各氏に媣く感謝致します。

\section{交献}

1) 松宮徹, 佐们 数, 四中純, 有占敏应：鉄と 鋼, 68 (1982)，p. 1782

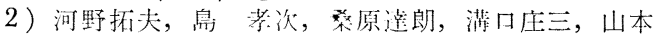
利樹，三隅秀当，常湖 聡：鉄と鋼，68 (1982)， p. 1764

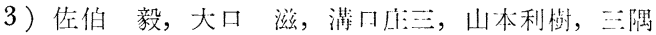
秀幸，常岡 聡：鉄と鋼，68（1982），p. 1773

4 ) 中野武人, 藤 雅雄, 永野恭一, 满17等: , 山本 利樹，浅野敬輔：鉄と銅，67 (1981)， p. 1210

5 ) 特別報少書 No. 29 鋼材の強制冷却 (1978), p. 48 [日本鉄鋼協会]

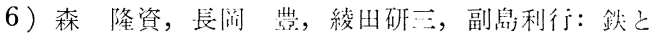
鋼, 60 (1974), p. 1033

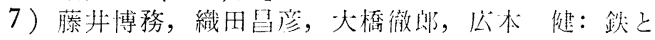
鋼, 62 (1976), S 93

8 ) 鈴木洋夫，西村 哲，山口重裕：鉄と銅，65 (1979), p. 2038

9 ). 鈴木洋夫, 西村 哲, 今村 淙, 中村溙：鉄之 鋼, 67 (1981), p. 1180

10）鈴木洋夫，西村 折，中村 泰：鉄と銅， 67 (1981), S 171

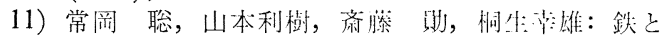
鋼, 66 (1980), S 808

12）三隅秀幸，满口庄三，住们毅，大山谈，川中 純：鉄之鋼，66(1980)，S 809 